\title{
Genes and Environmental Exposures in Veterans with Amyotrophic Lateral Sclerosis: The GENEVA Study
}

Rationale, Study Design and Demographic Characteristics

Silke Schmidt ${ }^{a}$ b Kelli D. Allen ${ }^{b, c}$ Valerie T. Loiacono ${ }^{a, b}$ Barbara Norman ${ }^{b, c}$

Catherine L. Stanwyck ${ }^{a, b} \quad$ Kristina M. Nord ${ }^{a, b} \quad$ Christina D. Williams $^{a, b}$

Edward J. Kasarskis ${ }^{\text {e }}$ Freya Kamel $^{d}$ Valerie McGuire ${ }^{f}$ Lorene M. Nelson $^{f}$

Eugene Z. Oddone ${ }^{b, c}$ VA ALS Registry Group

${ }^{a}$ Center for Human Genetics and ${ }^{b}$ Department of Medicine, Duke University Medical Center, and ${ }^{\mathrm{C}}$ Epidemiology Research and Information Center, Durham VAMC, Durham, N.C., 'Epidemiology Branch, National Institute of Environmental Health Sciences, Research Triangle Park, N.C., ' Lexington VAMC and University of Kentucky Medical Center, Lexington, Ky., and ${ }^{\mathrm{f}}$ Stanford University School of Medicine, Stanford, Calif., USA

\section{Key Words}

Amyotrophic lateral sclerosis, case-control study • GENEVA study recruitment methods · Gene-environment interaction vironmental risk factor information are described here, along with a summary of demographic characteristics of the participants (537 cases, 292 controls) enrolled to date.

Copyright $\odot 2008$ S. Karger AG, Basel

\section{Introduction}

Amyotrophic lateral sclerosis (ALS) is a devastating, incurable and fatal disorder of the motor neurons, the highly specialized cells in the brain and spinal cord responsible for all voluntary muscle movement. The progressive degeneration of motor neurons prevents communication between the nervous system and the body's muscles, leading to muscle spasticity, atrophy, fasciculations and ultimately paralysis. Death typically occurs within 2-4 years of symptom onset. With 1-2 newly diagnosed cases per 100,000 person-years, the incidence of ALS in the United States is similar to that of multiple sclerosis, but its prevalence is much lower due to the high

\section{KARGER}

두 2008 S. Karger AG, Base

Fax +41613061234

E-Mail karger@karger.ch

www.karger.com www.karger.com/ned
Silke Schmidt, $\mathrm{PhD}$

Center for Human Genetics, Department of Medicine

Duke University Medical Center, Box 3445

Durham, NC 27710 (USA)

Tel. +1 919684 0624, Fax +1 919684 0925, E-Mail silke.schmidt@duke.edu 
mortality; the cumulative lifetime risk is estimated to be 1 in 1,000 for those reaching adulthood [1]. The incidence of ALS is $20-60 \%$ higher in men than in women $[2,3]$, sharply increases after 40 years of age and, in many study populations, peaks between 55 and 65 years [4]. The incidence was recently reported to be twice as high in nonHispanic Caucasians, compared to African, Asian and Hispanic ethnicities [5].

Several genes have been identified for familial (Mendelian) forms of the disease. The majority of these are inherited in a dominant manner; thus, patients with these ALS forms are typically recognized in clinic by the presence of at least 1 affected first-degree relative. All inherited forms of ALS together account for approximately 5 $10 \%$ of all cases [6]. Mutations in the superoxide dismutase 1 gene (SOD1, MIM 147450) are responsible for $20 \%$ of familial ALS [6,7]; thus, at most $2 \%$ of all ALS patients are attributed to this cause. While the known Mendelian genes may lead to an earlier onset of the disease [8], the clinical phenotype of familial ALS is otherwise identical to sporadic ALS. Several other genes for forms of ALS have been localized or identified and hold promise for an improved understanding of the molecular chain of events involved in the onset and progression of this disease subtype $[6,9]$.

In contrast, the genetic contributions to the far more common (90-95\%) sporadic form of the disease are poorly understood. Research to date suggests that sporadic ALS is likely due to a combination of multiple genetic and environmental factors, which may interact in complex ways $[10,11]$. Putative susceptibility genes for sporadic ALS that have been supported by at least 2 studies include the vascular endothelial growth factor (VEGF) [12-14], the angiogenin $(A N G)[15,16]$ or nearby apurinic endonuclease (APEX) gene [15, 17], the hemochromatosis gene (HFE) $[18,19]$, the survival motor neuron genes (SMN1, $S M N 2)[20,21]$ and the cluster of paraoxonase genes on chromosome 7q (PON1, PON2, PON3) [22-25]. The PON genes are of particular interest for testing the hypothesis of gene-environment interaction in ALS since PON1 is involved in the detoxification of organophosphate pesticides and chemical nerve agents $[26,27]$. The apolipoprotein $\mathrm{E}(A P O E)$ gene has been examined in multiple studies, most of which did not support an association with the risk of sporadic ALS; however, carriers of the APOE-4 allele tended to experience more rapid disease progression, shorter survival and possibly an earlier age of onset, supporting APOE as a modifier gene [28-31]. The results of 4 genome-wide association studies have recently been reported [32-35]. A joint analysis of 3 of these studies im- plicated the dipeptidyl-peptidase $6(D P P 6)$ gene as a plausible ALS susceptibility gene with potentially relevant biological function [35], and this finding is awaiting replication in other data sets.

A number of putative environmental risk factors for sporadic ALS have been examined, most of them with inconsistent findings across studies. Some of the more consistently reported associations include exposure to pesticides and agricultural occupation [36-38], exposure to lead $[36,38-46]$ and possibly other heavy metals [4345], cigarette smoking [47-49], intense physical activity including professional soccer playing [50-52] and head injury $[36,53-60]$. The importance of environmental risk factors suggests a potential involvement of genes in xenobiotic metabolism pathways. Examples of such genes include $P O N 1$, as mentioned above, and the $\delta$-aminolevulinic acid dehydratase (ALAD) gene, which plays an important and well-characterized role in lead metabolism and has been implicated as a susceptibility gene for sporadic ALS [61].

Of particular relevance for the study described here, an approximately two-fold risk of ALS was reported for veterans of the 1990-1991 Persian Gulf War [62-64], and for the much larger population of all US veterans [65]. These studies were recently evaluated by an Institute of Medicine committee [66]. The Gulf War studies prompted the Department of Veterans Affairs (VA) to fund the establishment of a nationwide registry charged with the goal of identifying and enrolling all living veterans with ALS. This study is referred to as the National Registry of Veterans with ALS [67] and its recruitment methods are described in more detail in a companion paper [Allen et al., this issue]. The VA registry includes blood collections and the establishment of a DNA bank for registry participants [68].

The goal of the Genes and Environmental Exposures in Veterans with ALS (GENEVA) case-control study described here is to evaluate the joint effects of genetic susceptibility and environmental factors on the risk of ALS in US veterans, with a focus on identifying gene-environment interactions. The cases enrolled into the GENEVA study are a subset of those enrolled into the VA registry. The specific aims of the study are to recruit an appropriate group of veteran controls, collect their DNA samples, administer an extensive structured telephone interview about environmental exposures to both ALS cases and controls, and genotype case and control samples for polymorphisms in ALS candidate genes. We describe below the study design and recruitment strategies used in the GENEVA study. 


\section{Materials and Methods}

\section{Case Identification}

Patients were enrolled into the National Registry of Veterans with ALS from April 1, 2003 through September 30, 2007. The registry employed 2 primary methods for identifying cases, which are described in detail in the companion paper [Allen et al., this issue] and briefly summarized here. The first recruitment method, referred to as 'active', identified veterans who were using the VA system for obtaining some or all of their health care and involved periodic searches of national VA inpatient and outpatient databases for the presence of an ICD-9 (International Classification of Diseases, 9th Revision, Clinical Modification) code of 335.2X [motor neuron diseases (MND)]. The VA databases maintained the ICD-9 coding system during the registry enrollment period. The highest enrollment priority was assigned to individuals with an ALS-specific ICD-9 code of 335.20. A small proportion of registry enrollees [Allen et al., this issue] were contacted because they had previously participated in the VA-funded Gulf War study of ALS, which used similar active and passive recruitment methods [64]. The identified veterans were mailed an introductory letter and then called for screening. The second method of case identification, referred to as 'passive', consisted of regular distribution of study brochures and mass mailings to nationwide ALS specialty clinics and neurologists identified from American Academy of Neurology and VA neurology service listings. The registry was also publicized on ALS-related websites, including the National ALS Association (ALSA) (http://www.alsa.org), local ALSA chapters and the ALS Division of the Muscular Dystrophy Association (http://www.als-mda.org). Veterans, their family members or other caregivers were invited to contact the study team at any time via a toll-free telephone number, mail, e-mail or a secure web-based enrollment tool linked to the ALS registry website.

Following informed consent, the enrollees' medical records were reviewed by neurologists specializing in ALS, using the World Federation of Neurology Revised El Escorial ALS Diagnostic Criteria $[69,70]$. Each patient was classified into 1 of the following categories: clinically definite ALS, clinically probable ALS, clinically probable and lab supported ALS, clinically possible ALS, suspected ALS (including progressive muscular atrophy, progressive bulbar palsy and primary lateral sclerosis), indeterminate or no ALS/MND. Consent to participate in the registry-affiliated DNA bank was obtained by a separate process, as described elsewhere [68]. Once a confirmed diagnosis of 'no ALS/MND' was established for original registry participants, they were not included in follow-up interviews. If a blood sample had been obtained prior to arriving at this diagnosis, it was destroyed.

For the GENEVA study, which was approved by the Institutional Review Boards of the Durham VAMC and Duke University Medical Center, eligible veterans included living registry enrollees who were classified as clinically definite ALS, clinically probable ALS, clinically probable and lab supported ALS, clinically possible ALS, PMA or PBP, who had consented to participate in the DNA bank and who had agreed to be contacted about other ALS-related studies. Future enrollment efforts will also include PLS cases who participated in the DNA bank and gave contact permission.

\section{Selection of Potential Controls}

To identify an appropriate source population of potential veteran controls, in June 2005 we obtained a random sample of
10,000 records from the Beneficiary Identification and Record Locator System (BIRLS) database maintained by the Veterans Benefit Administration (VBA). This database contains records of all US veterans with a release of active duty (RAD) date of 1973 or later, and a subset of veterans with an earlier RAD. Starting in 1973, database systems at both VBA and the Defense Manpower Data Center maintained by the Department of Defense relied on the requirement for all military service personnel to submit a specific release form (DD214) at the time of their discharge. At VBA, the BIRLS database serves primarily to verify a person's veteran status when a claim for any VA benefit is processed. The records prior to 1973 largely represent the subset of all veterans that actively contacted the Department of Veterans Affairs by submitting any type of benefit application, all veterans whose surviving relatives applied for death benefits and all Medal of Honor recipients. VA benefits include a wide range of services. According to the most recent National Survey of Veterans conducted in 2001 (NSV 2001, http://wwwl.va.gov/vetdata/page. cfm?pg=5), 24\% of all US veterans use VA health care, either exclusively or in addition to non-VA health care, $14 \%$ receive service-connected disability benefits, $40 \%$ use educational and vocational training benefits, $47 \%$ use the home loan guarantee program and $11 \%$ are covered by VA life insurance. The total number of 'master records' in BIRLS is estimated to be 44 million [71]. The percentage of US veterans who were alive during the registry enrollment period but not represented in the BIRLS database is unknown. However, this approach was a reasonable and administratively feasible mechanism for identifying a representative sample of the estimated 25 million US veterans.

The primary source of vital status information in BIRLS is the submission of a copy of the veteran's death certificate to the Department of Veterans Affairs for death benefits. Previous studies reported high accuracy rates of BIRLS for ascertaining vital status, with a range from 80 to $95 \%$ [72-74], although BIRLS is considered inferior to the National Death Index and lacks reliable information on the cause of death. At the time of our request to VBA, the total number of unique non-deceased records in BIRLS with birth years ranging from 1900 to 1980 was 21.2 million [D. Cohen, pers. commun.]. For the purpose of this study, we requested 2,000 non-deceased records from each of the following 5 birth cohort categories, with the respective number of total records at the time of our request listed in parentheses: 1900-1930 (2.5 million), 1931-1940 (1.8 million), 1941-1950 (4 million), 1951-1960 (5 million) and 1961-1980 (7.8 million). Sampling was performed based on a random number generated from the system date. The BIRLS extracts also included partial information on sex (available for $69 \%$ of the 10,000 records), the most recent RAD (80\%) and military service branch (78\%). Since BIRLS does not contain reliable current contact information, the Durham VAMC entered into an interagency agreement with the National Institute of Occupational Safety and Health to access Internal Revenue Service (IRS) mailing address databases. Annual data merges provided addresses from the most recent tax filing date. We also cross-checked the BIRLS data extract against the VA National Enrollment Database in order to match cases and controls on past VA health care use.

Control Recruitment and Matching Strategy

The GENEVA study design aimed to frequency-match cases and controls on age, sex, race/ethnicity and use of the VA system for health care (for cases, prior to the date of their first ALS diag- 
nosis). It is well known that socioeconomic differences exist between veterans who rely solely on the VA for health care and those who use other systems [75]; however, ALS cases may switch from other health care providers to the VA as a consequence of their disease and its associated medical care costs. This was, in fact, the case for $23 \%$ of GENEVA cases, who reported not having used the VA for health care prior to their first diagnosis but identified themselves as current VA users when they enrolled into the ALS registry. Unfortunately, the BIRLS database includes no information on race/ethnicity and only partial information on sex; thus, the only 2 variables available for the entire database extract prior to inviting potential controls were age and VA health care use, based on the cross-check against the National Enrollment Database in December 2005. Mailing batches of 100-300 potential controls were frequency-matched to ALS cases on the basis of their date of birth, using 5-year categories of age at the first ALS diagnosis (reference age) as the target frequencies, and on the basis of a record match with the VA National Enrollment Database, using the proportion of GENEVA cases who reported VA health care use prior to their diagnosis as the target frequency. This is an imperfect surrogate variable since VA health care use may change over time.

Control recruitment strategies incorporated elements of the Dillman method [76], as described below. This strategy was originally designed to maximize the response rate for mailed study questionnaires. After an invitation letter and study brochure were mailed, up to 3 reminder letters were sent within the next 2 months. The reminder letters included a response form and stamped return envelope for providing a current telephone number and preferred contact time. Alternatively, subjects could return the response form to opt out of participation and prevent further contact attempts. They were informed that they might be contacted by telephone if they did not respond in either way. Telephone contact attempts at different times of day were made with both responders and nonresponders, with highest enrollment priority assigned to individuals who returned the opt-in response form. For nonresponders, telephone numbers were identified through freely available internet search engines and a commercial locator.

During the first telephone contact with a potential control participant, a telephone screener was administered to confirm that the individual was a US veteran and to determine study eligibility. Consistent with previous epidemiologic studies [35, 42], exclusion criteria included the presence of ALS or other neurological disorders (Alzheimer disease and other forms of dementia, Parkinson disease, multiple sclerosis, postpolio syndrome, myasthenia gravis and any neuropathies) by self-report. Subjects were also ineligible if they reported the presence of progressive muscle weakness. Consented participants were mailed occupational and residential history worksheets and a life timeline with a request to review (but not send back) these forms prior to the telephone interview for assistance with recall. A separate mailing included the Oragene saliva collection kit (DNA Genotek Inc., Ottawa, Ont., Canada) with detailed instructions and color photographs of how to collect a saliva sample. DNA was extracted from the saliva samples using PureGene (Gentra Systems Inc., Minneapolis, Minn., USA) chemistry according to the manufacturer's protocol.

\section{Study Questionnaire and Data Quality Monitoring}

Most of our study questionnaire was composed of modules developed by the ALS Consortium of Epidemiologic Studies (http://aces.stanford.edu). Military-specific sections were adapted from questionnaires used in the Iowa Gulf War study [78] and the Millennium Cohort Study [79]. We also used the validated Posttraumatic Stress Disorder Checklist (military version) [8082]. This instrument was shown to be highly specific (0.99) with lower sensitivity (0.60), for a positive predictive value of $75 \%$ and negative predictive value of $97 \%$ when using a cutoff of 50 on a scale of 17-85 [83]. Study interviews were conducted by the Durham VAMC-based staff as well as interviewers at Social and Scientific Systems Inc. (Durham, N.C., USA), who were trained by the VAMC-based staff. Data were recorded on hard copies and entered into an Oracle database (PEDIGENE ${ }^{\circledR}$, Duke University Medical Center, Durham, N.C., USA). For cases, exposures were ascertained up to a reference date, which was the month and year of their first physician-confirmed ALS diagnosis. This date is generally considered more reliable and precise than the self-reported symptom onset date. Given that the median number of months between the self-reported symptom onset and the first ALS diagnosis in GENEVA cases was 13.0 months, which is comparable to previous studies [84], any exposures that may have occurred after symptom onset account for a very short time period relative to a lifetime environmental exposure history. The reference date for controls was the interview date. For most exposures, information about the relevant duration was recorded as well. Throughout the interview, a lifetime calendar of major personal events was used to enhance the subject's ability to recall their exposure history. Periodic quality control checks of up to $25 \%$ of interviews were performed by comparing the complete interview hard copy to the database entries.

The occupational history data were manually coded as follows: Industries were assigned North American Industry Classification System 2002 codes developed by the US Census Bureau (http://www.census.gov/epcd/naics02). Job titles were assigned Standard Occupational Classification 2000 codes developed by the US Department of Labor (http://www.bls.gov/soc/home. htm). For jobs held during military service, we used the coding system implemented in the Millennium Cohort Study questionnaire [M. Ryan, pers. commun.] with separate occupational categories for job titles of enlisted service members versus officers or warrant officers. Subjects were queried about all job tasks performed in each job title and the materials used for each task. To facilitate statistical analyses, we coded job tasks and materials by reviewing job-title-specific modules originally developed by the National Cancer Institute $[85,86]$ and revised for neuroepidemiologic studies. The review of these modules generated a list of job tasks with potential for exposure to neurotoxic agents and a list of typical materials used in 1 or more of these tasks. During the manual review of each respondent's occupational history, job tasks and materials mentioned by the respondent received a numeric code from this list whenever a match of either task or material was found.

\section{Statistical Analysis}

The statistical comparisons of currently enrolled cases and controls shown in tables 1 and 2 were performed with the SAS software (SAS Institute Inc., Cary, N.C., USA), using either a $\chi^{2}$ or Fisher's exact test for categorical variables and a t test for continuous variables. The power calculations were performed with the QUANTO software (http://hydra.usc.edu/gxe) [77]. 
Table 1. Demographic characteristics of GENEVA cases and controls (as of October 2007), compared to potential controls who refused to participate or could not be contacted by telephone and to the US veteran population per 2001 National Survey of Veterans

\begin{tabular}{|c|c|c|c|c|c|c|c|}
\hline & Variable $^{\mathrm{a}}$ & $\begin{array}{l}\text { GENEVA } \\
\text { cases } \\
(\mathrm{n}=537)\end{array}$ & $\begin{array}{l}\text { GENEVA } \\
\text { controls } \\
(\mathrm{n}=292)\end{array}$ & $\mathrm{p}$ value & $\begin{array}{l}\text { Controls: refusal } \\
\text { to participate } \\
(\mathrm{n}=689)\end{array}$ & $\begin{array}{l}\text { Controls: } \\
\text { no telephone } \\
\text { contact }(n=673)\end{array}$ & $\begin{array}{l}\text { US veterans } \\
(\mathrm{n} \approx 25,000,000)\end{array}$ \\
\hline \multirow[t]{2}{*}{ Sex } & Male & 97.6 & 93.8 & \multirow[t]{2}{*}{0.01} & 96.6 & 93.8 & 94.1 \\
\hline & Female & 2.4 & 6.2 & & 3.4 & 6.2 & 5.9 \\
\hline \multirow[t]{12}{*}{ Age $^{\mathrm{b}}$, years } & Less than 35 & 2.2 & 1.0 & \multirow[t]{11}{*}{0.002} & 0.7 & 5.8 & 9.1 \\
\hline & $35-39$ & 4.1 & 1.4 & & 2.6 & 10.4 & 5.3 \\
\hline & $40-44$ & 5.2 & 3.4 & & 2.8 & 8.3 & 6.7 \\
\hline & $45-49$ & 6.0 & 5.1 & & 7.1 & 10.0 & 8.1 \\
\hline & $50-54$ & 10.4 & 7.9 & & 6.3 & 14.0 & 13.4 \\
\hline & $55-59$ & 17.9 & 17.8 & & 16.3 & 15.4 & 11.1 \\
\hline & $60-64$ & 18.8 & 17.5 & & 13.9 & 14.1 & 8.6 \\
\hline & $65-69$ & 15.1 & 13.4 & & 12.2 & 8.5 & 10.1 \\
\hline & $70-74$ & 12.3 & 14.0 & & 14.4 & 5.6 & 10.7 \\
\hline & $75-79$ & 6.5 & 14.4 & & 14.2 & 5.4 & 9.5 \\
\hline & $>79$ & 1.5 & 4.1 & & 9.6 & 2.5 & 6.8 \\
\hline & Mean $\pm \mathrm{SD}$ & $59.6 \pm 11.4$ & $63.3 \pm 11.0$ & $<0.0001$ & $64.4 \pm 12.3$ & $54.6 \pm 13.2$ & $58.0(\mathrm{SD} \mathrm{n} / \mathrm{a})$ \\
\hline \multirow[t]{4}{*}{ Race } & White & 92.4 & 91.1 & \multirow[t]{4}{*}{0.59} & \multirow[t]{4}{*}{$\mathrm{n} / \mathrm{a}$} & \multirow[t]{4}{*}{$\mathrm{n} / \mathrm{a}$} & 84.8 \\
\hline & Black & 3.5 & 4.1 & & & & 8.8 \\
\hline & Multiple & 2.4 & 2.8 & & & & 2.2 \\
\hline & Other/unknown & 1.6 & 2.0 & & & & 4.2 \\
\hline \multirow[t]{3}{*}{ Ethnicity } & Hispanic/Latino & 2.6 & 3.1 & \multirow[t]{3}{*}{0.69} & \multirow[t]{3}{*}{$\mathrm{n} / \mathrm{a}$} & \multirow[t]{3}{*}{$\mathrm{n} / \mathrm{a}$} & 4.5 \\
\hline & Not Hispanic/Latino & 97.4 & 96.9 & & & & 95.2 \\
\hline & Unknown & 0 & 0 & & & & 0.3 \\
\hline \multirow{2}{*}{$\begin{array}{l}\text { Use of VA } \\
\text { health care }\end{array}$} & Ever & 37.9 & 45.6 & \multirow[t]{2}{*}{0.05} & $31.9^{c}$ & $40.7^{\mathrm{c}}$ & 24.4 \\
\hline & Never & 62.1 & 54.4 & & 68.1 & 59.3 & 76.6 \\
\hline \multirow{2}{*}{$\begin{array}{l}\text { Application for } \\
\text { VA benefits }\end{array}$} & Ever & 76.4 & 82.5 & \multirow[t]{2}{*}{0.06} & \multirow[t]{2}{*}{$\mathrm{n} / \mathrm{a}$} & \multirow[t]{2}{*}{$\mathrm{n} / \mathrm{a}$} & \multirow[t]{2}{*}{$\mathrm{n} / \mathrm{a}$} \\
\hline & Never & 23.6 & 17.5 & & & & \\
\hline \multirow[t]{7}{*}{ Education } & Less than high school & 3.5 & 1.0 & \multirow[t]{6}{*}{0.01} & \multirow[t]{7}{*}{$\mathrm{n} / \mathrm{a}$} & \multirow[t]{7}{*}{$\mathrm{n} / \mathrm{a}$} & 11.1 \\
\hline & High school diploma & 41.5 & 34.6 & & & & 29.9 \\
\hline & Post-high-school diploma & 18.3 & 21.2 & & & & 35.8 \\
\hline & College degree & 22.5 & 21.6 & & & & 23.0 (college or \\
\hline & Graduate degree & 13.6 & 20.1 & & & & graduate degree) \\
\hline & Other/unknown & 0.6 & 1.4 & & & & 0.2 \\
\hline & $\begin{array}{l}\text { Years of schooling: } \\
\text { mean } \pm S D\end{array}$ & $14.5 \pm 2.8$ & $15.2 \pm 3.1$ & 0.001 & & & $\mathrm{n} / \mathrm{a}$ \\
\hline \multirow{5}{*}{$\begin{array}{l}\text { Employment } \\
\text { status }\end{array}$} & Employed & 54.9 & 44.9 & $0.002^{\mathrm{d}}$ & $\mathrm{n} / \mathrm{a}$ & $\mathrm{n} / \mathrm{a}$ & 54.9 \\
\hline & Retired & 36.9 & 49.3 & & & & 32.0 \\
\hline & Disabled & 6.7 & 3.8 & & & & 6.9 \\
\hline & Full-time student & 0.2 & 0 & & & & 0.4 \\
\hline & Unemployed & 1.3 & 2.1 & & & & 4.8 \\
\hline Marital status & Never married & 1.9 & 4.1 & 0.04 & $\mathrm{n} / \mathrm{a}$ & $\mathrm{n} / \mathrm{a}$ & 7.2 \\
\hline & Married/living with partner & 87.7 & 83.6 & & & & 74.9 \\
\hline & Separated/divorced & 7.5 & 6.5 & & & & 12.3 \\
\hline & Widowed & 3.0 & 5.8 & & & & 5.3 \\
\hline
\end{tabular}

$\mathrm{n} / \mathrm{a}=$ Not available.

${ }^{a}$ Prior to first ALS diagnosis for cases; prior to interview date for controls. ${ }^{b}$ Age at first ALS diagnosis for cases; age at interview for controls. ' Based on record match with VA National Enrollment Database. ' Based on categories 'employed' 'retired' and 'other'. 
Table 2. Military service characteristics of cases and controls enrolled in the GENEVA study (as of October 2007), compared to potential controls who refused to participate or could not be contacted by telephone and to the US veteran population per 2001 National Survey of Veterans

\begin{tabular}{|c|c|c|c|c|c|c|}
\hline Variable & $\begin{array}{l}\text { GENEVA } \\
\text { cases } \\
(\mathrm{n}=537)\end{array}$ & $\begin{array}{l}\text { GENEVA } \\
\text { controls } \\
(\mathrm{n}=292)\end{array}$ & $\mathrm{p}$ value & $\begin{array}{l}\text { Controls: refusal } \\
\text { to participate } \\
(\mathrm{n}=689)\end{array}$ & $\begin{array}{l}\text { Controls: no } \\
\text { telephone contact } \\
(\mathrm{n}=673)\end{array}$ & $\begin{array}{l}\text { US veterans } \\
(\mathrm{n} \approx 25,000,000)\end{array}$ \\
\hline \multicolumn{7}{|l|}{ Deployment $^{\mathrm{a}}$} \\
\hline WWII & 5.6 & 3.8 & 0.31 & $\mathrm{n} / \mathrm{a}$ & $\mathrm{n} / \mathrm{a}$ & 12.3 \\
\hline Korea & 7.0 & 11.0 & 0.05 & & & 7.2 \\
\hline Vietnam & 24.3 & 29.2 & 0.13 & & & 17.4 \\
\hline Persian Gulf War & 2.7 & 2.4 & 1.0 & & & 5.3 \\
\hline None of the above & 59.0 & 55.1 & 0.28 & & & 60.1 \\
\hline \multicolumn{7}{|l|}{ Military pay grade } \\
\hline Enlisted & 74.0 & 69.2 & 0.32 & $\mathrm{n} / \mathrm{a}$ & $\mathrm{n} / \mathrm{a}$ & $\mathrm{n} / \mathrm{a}$ \\
\hline Officer & 15.5 & 18.8 & & & & \\
\hline Neither ${ }^{b}$ & 10.5 & 12.0 & & & & \\
\hline \multicolumn{7}{|c|}{ Branch of most recent active duty service ${ }^{c}$} \\
\hline Army & 40.4 & 37.0 & 0.30 & 42.2 & 46.0 & 50.2 \\
\hline Navy & 22.0 & 20.9 & & 23.1 & 21.3 & 24.4 \\
\hline Air Force & 21.8 & 23.6 & & 25.5 & 23.2 & 19.6 \\
\hline Marine Corps ${ }^{\mathrm{d}}$ & 9.7 & 8.6 & & 7.4 & 8.6 & 11.9 \\
\hline Coast Guard & 1.1 & 1.0 & & 1.8 & 0.9 & 1.4 \\
\hline Activated Reserves/Guard & 3.7 & 5.4 & & $\mathrm{n} / \mathrm{a}$ & $\mathrm{n} / \mathrm{a}$ & $\mathrm{n} / \mathrm{a}$ \\
\hline Other & 1.3 & 3.4 & & 0.2 & 0 & 2.2 \\
\hline \multicolumn{7}{|c|}{ Most recent release of active duty date $\mathrm{e}^{\mathrm{e}}$} \\
\hline 9/1940-7/1947 & 6.4 & 3.4 & 0.01 & 4.3 & 2.0 & 20.5 \\
\hline $8 / 1947-5 / 1950$ & 0.9 & 0.7 & & 0.8 & 0.5 & 6.7 \\
\hline $6 / 1950-1 / 1955$ & 9.9 & 9.3 & & 5.3 & 2.4 & 6.7 \\
\hline 2/1955-7/1964 & 23.4 & 15.4 & & 14.7 & 7.9 & 16.9 \\
\hline $8 / 1964-4 / 1975$ & 31.8 & 32.2 & & 34.5 & 31.5 & 25.6 \\
\hline $5 / 1975-8 / 1980$ & 6.7 & 11.6 & & 14.7 & 15.4 & 36.1 \\
\hline $9 / 1980-7 / 1990$ & 8.2 & 11.3 & & 15.3 & 18.6 & 27.9 \\
\hline $8 / 1990$ or later & 12.7 & 16.1 & & 10.4 & 21.7 & 13.9 \\
\hline
\end{tabular}

a GENEVA data refers to question 'Were you ever deployed to...'; National Survey of Veterans (2001) data refers to question 'Have you served in combat or war zone....

b Service prior to the end of the draft (1973).

${ }^{c}$ National Survey of Veterans (2001) data refers to "ever having served on active duty" rather than most recent active duty branch, thus more than one branch may have been indicated; branches with predominantly female service personnel (Women's Army Auxiliary Corps, Women's Army Corps, Women Accepted for Voluntary Emergency Service, Navy Nursing Corps, Air Force Nursing Corps, Women's Air Force Service Pilots, Coast Guard Women's Reserve) not included in 'other' category.

${ }^{\mathrm{d}}$ Including US Merchant Marines.

e Categories from 2000 US Census, with addition of 8/1947-5/1950.

\section{Results}

Case enrollment for GENEVA started in May 2005, and control enrollment in January 2006; both efforts are still ongoing, with case enrollment approximately $85 \%$ and control enrollment approximately 30\% complete. Figure 1a illustrates the recruitment process for the VA registry enrollees who were invited to participate in the
GENEVA study to date. Screening methods prior to medical record review of the 2,089 registry enrollees $(2,066$ with confirmed ALS or MND diagnosis) are described in the companion paper [Allen et al., this issue], which also provides information about the geographic distribution of all enrollees and the reliability of the ICD-9 diagnosis codes within the VA databases. Of the 537 GENEVA cases enrolled and interviewed to date, 33\% were self-re- 
Fig. 1. a Ascertainment of GENEVA cases. * Withdrawal before collection: 56.2\%; ineligible after medical record review (no MND): $23.1 \%$; closeout: $10.8 \%$; sample could not be obtained during nurse visit: $10.0 \%$. ${ }^{*}$ Reasons for ineligibility: presence of Alzheimer disease or other form of dementia $(n=5)$; change in disease status by time of first contact (to PLS, indeterminate or no MND) $(n=8)$; withdrawal from the registry or its DNA bank by the time of first contact $(n=2)$; telephone interview not feasible for other reasons $(n=4)$. $\mathbf{b}$ Ascertainment of GENEVA controls. * Correct telephone number could not be identified: $57.8 \%$; closeout after leaving multiple voicemail messages: $37.7 \%$; no answering machine, and telephone was never picked up: $4.5 \%$. ${ }^{* *}$ Reasons for ineligibility: not US veteran $(n=4)$; neuropathy $(n=9)$; Alzheimer disease or other form of dementia $(\mathrm{n}=7)$; Parkinson disease $(\mathrm{n}=4)$; multiple sclerosis $(\mathrm{n}=1)$; post-polio syndrome $(\mathrm{n}=1)$; myasthenia gravis $(\mathrm{n}=2)$; other $(n=3)$.
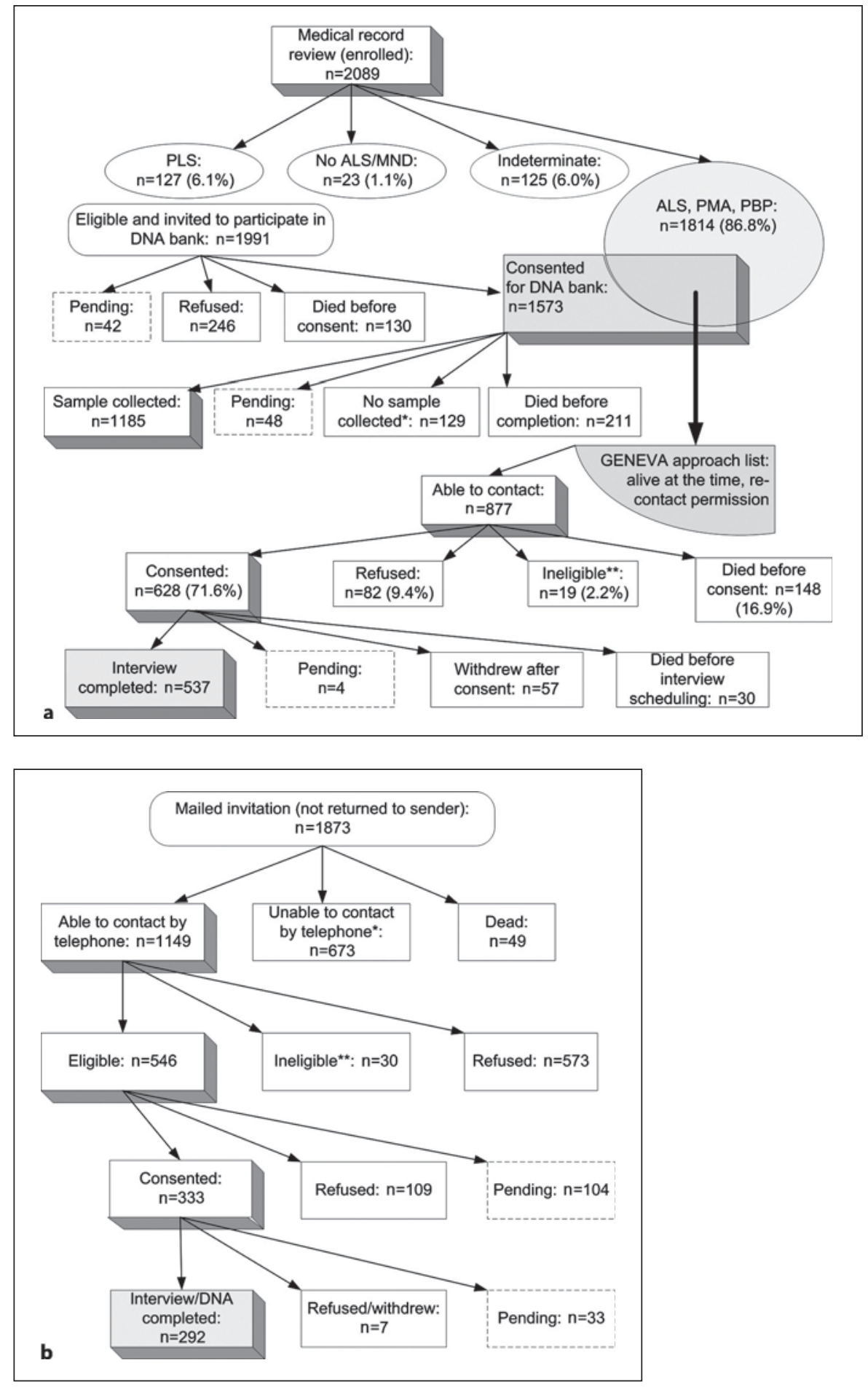

ferred only (not identified in a VA database), $43 \%$ were non-self-referred and $24 \%$ were both self-referred and identified in a VA database, but contacted the registry team before any recruitment material was sent to them. Thirty-two percent of GENEVA cases $(n=173)$ were en- rolled into the registry within 12 months of their first ALS diagnosis, and thus considered incident; $45 \%$ were enrolled within 18 months. Figure $1 \mathrm{~b}$ illustrates the enrollment process for the GENEVA controls. Of the 10,000 randomly sampled veterans from BIRLS, the match rate 
for the annual IRS mailing address merge facilitated by the National Institute of Occupational Safety and Health was $89 \%$. Sixty-eight percent of the 10,000 veterans had not used the VA for health care prior to December 2005, according to the cross-check against the National Enrollment Database. Of the 1,022 eligible individuals who could be contacted by mail and telephone (excluding those whose final outcome is pending), 333 consented, for a cooperation rate of $32.6 \%$.

Tables 1 and 2 show a comparison of matching variables and other demographic and military service characteristics for the cases and controls enrolled to date. In these tables, information from the BIRLS database is included for the invited controls who could be contacted (at least once) by telephone but refused, actively or passively, to participate $(n=689)$, and for those whose mailed invitation letters were not returned but with whom telephone contact could never be established for various reasons ( $n=673$ ). In addition, corresponding data from the general population of US veterans per 2001 National Survey of Veterans is shown. Survey data were collected from 20,048 veterans, and weighting methods based on the probability of selection, survey nonresponse and households with more than 1 telephone number were used to represent the entire noninstitutionalized US veteran population (http://wwwl.va.gov/vetdata/page.cfm?pg=5). Table 1 shows that the GENEVA cases and controls enrolled to date were well matched on race/ethnicity, despite the lack of prior information about these variables. While the vast majority ( $>93 \%)$ of both cases and controls were male, the proportion of female participants was significantly higher in controls than cases $(\mathrm{p}=0.01)$ since females were less likely to refuse to participate. Furthermore, table 1 shows that it was more difficult to make telephone contact with younger veterans: $48.5 \%$ of those who could not be contacted, either due to an incorrect phone number or because they ignored multiple voicemail messages, were in the age group 35-54 years, compared to $19.5 \%$ of refusers and $18.8 \%$ of GENEVA controls. This shifted the age distribution of enrolled controls toward a significantly higher mean (63.3 years, compared to 59.6 years for cases) and significantly increased the proportion of retired controls compared to cases. The comparison between GENEVA controls and those who could be contacted by phone but actively or passively refused to participate, suggests that veterans who used the VA for health care were less likely than non-VA users to refuse participation once telephone contact was made. We are making an effort to achieve closer frequency matching on both age and VA health care use for the final sample that will be used for analysis.
The comparison with the National Survey of Veterans shows that the GENEVA participants (cases and especially controls) were more highly educated than the general population of US veterans. Partially due to the nature of ALS and the recruitment methods that were employed, they also included a lower proportion of younger veterans, a higher proportion of white males and a higher proportion of VA health care users. These demographic characteristics are likely responsible for other differences between GENEVA participants and the general veteran population for the variables shown in tables 1 and 2 (e.g. military branch and service period). However, within the study population, cases and controls were well matched on basic military characteristics (table 2).

The proportion of cases and controls who had ever applied for at least 1 form of VA benefit was similar overall [76.4\% of cases (prior to their ALS diagnosis), $82.5 \%$ of controls; $p=0.06]$. Not surprisingly, this proportion varied somewhat by discharge period and case-control status. For example, $68.2 \%$ of cases versus $82.1 \%$ of controls discharged during the Korea and pre-Vietnam era reported that they had applied for some form of VA benefit. For the Vietnam era (1964-1975), the respective proportions were similar ( $82.6 \%$ of cases, $86.2 \%$ of controls), and this was also true for subsequent periods. We will adjust future analyses of environmental exposure data for these observed differences, which are partially due to the fact that potential GENEVA controls were identified through the BIRLS database.

Table 3 summarizes the broad categories of the environmental exposure information collected during the telephone interview. Since ALS may affect the muscles used for speech, $22 \%$ of the case interviews $(n=119)$ were conducted with assistance from the patient's caregiver, typically the spouse. In the majority of these interviews (83\%), the respondent communicated with the participant, while $17 \%$ were true proxy interviews. Many patient interviews were conducted during the course of multiple phone calls, to ease the burden on the patient and caregiver. Of the 173 incident GENEVA cases who were enrolled into the registry within 12 months of their first ALS diagnosis, 116 (67\%) were interviewed within 18 months.

Blood samples from ALS patients were obtained for $85 \%$ of registry patients who participated in the DNA bank; for the remaining $15 \%$, only a mouthwash sample was available. The DNA extractions using saliva samples obtained from the GENEVA controls provided a median yield of $43 \mu \mathrm{g}$ (mean $75 \mu \mathrm{g}$, range $0.4-716 \mu \mathrm{g}$, excluding samples without any DNA). We received 3 samples with- 
out any DNA and 7 samples with $<5 \mu$ g yield, which was typically due to an insufficient amount of saliva in the vial or occasional spills due to improper sealing of the vial. For all samples with $<5 \mu$ g yield, a second sample was requested from the participant.

The companion paper [Allen et al., this issue] describes the clinical variables that have been collected from all registry enrollees, including the GENEVA cases. As illustrated in figures 2 and 3, all registry enrollees with positive medical record review $(n=2,066)$, those who also participated in the DNA bank, and those who participated in both the DNA bank and the GENEVA study were comparable in terms of diagnostic breakdown and proportion of incident versus prevalent cases, based on the time between first ALS diagnosis and enrollment into the registry. The survival characteristics in the 3 patient groups conformed to the expected pattern, given the respective recruitment procedures, with a median of 25.5 months from first ALS diagnosis to death in registry participants ( $\mathrm{n}=1,032$ deceased), 28.1 months in DNA bank participants $(\mathrm{n}=364$ deceased) and 31.1 months in GENEVA participants ( $\mathrm{n}=116$ deceased).

We also compared the clinical characteristics of the GENEVA cases with respect to the recruitment method. The $57 \%$ of self-referred cases represented 3 major groups: $15.8 \%(\mathrm{n}=85)$ learned about the registry from their neurologist, 19.6\% $(\mathrm{n}=105)$ from ALSA and 21.8\% $(\mathrm{n}=117)$ from other publicity or word-of-mouth. Forty-three percent of GENEVA cases were non-self-referred. The proportion of cases with definite or probable ALS showed relatively little variation across recruitment method, with a range of $70.7 \%$ (non-self-referred) to $75.2 \%$ (non-ALSA publicity). The proportion of patients with bulbar onset was lowest (11.5\%) in those who self-referred based on non-ALSA publicity and highest (17.5\%) in those informed by their neurologist. The median survival time was 24.9 months in those informed by their neurologist, 26.5 months in those who self-referred based on nonALSA publicity, 38.0 months in those who self-referred based on ALSA publicity and 46.2 months in the nonself-referred group. The majority (85\%) of the 173 incident cases were self-referred.

Assuming a disease prevalence of 0.001 and 5\% significance level, the anticipated final sample (630 cases, 1,000 controls) will have $80 \%$ power to detect a main effect odds ratio (OR) of 1.35 for a binary environmental exposure with population frequency $30 \%$, and $80 \%$ power to detect a gene-environment interaction OR of 1.57 on the multiplicative scale, assuming absence of main effects and a $30 \%$ allele frequency with a log-additive mode of
Table 3. Categories of environmental exposure data collected by structured telephone interview

\begin{tabular}{ll}
\hline Category & Description \\
\hline $\begin{array}{l}\text { Demographics and } \\
\text { body habitus }\end{array}$ & $\begin{array}{l}\text { age, sex, race/ethnicity, origin of 4 } \\
\text { grandparents, years of schooling, highest } \\
\text { degree attained, employment status, } \\
\text { height, weight }\end{array}$ \\
\hline $\begin{array}{l}\text { Lifetime occupation- } \\
\text { al history }\end{array}$ & $\begin{array}{l}\text { job title, job tasks, materials used (per } \\
\text { task), protective equipment used (per } \\
\text { job title), level of physical activity for all } \\
\text { jobs held for at least 6 months }\end{array}$ \\
\hline $\begin{array}{l}\text { Home and military } \\
\text { pesticide use }\end{array}$ & $\begin{array}{l}\text { use of insecticides, herbicides, and fun- } \\
\text { gicides in home and garden; testing, } \\
\text { transporting or spraying herbicides for } \\
\text { military purposes }\end{array}$ \\
\hline
\end{tabular}

Consumption of to- cigarettes, cigars, pipes, alcohol, coffee, bacco, alcohol, caf- tea, caffeinated soft drinks (lifetime dufeinated drinks ration and dose)

Deployment and military history theaters of operation and specific exposures for deployments to WW II, Korea, Vietnam, Persian Gulf War; vaccination history, imminent danger and hardship duty pay, combat zone tax exclusion benefits

\begin{tabular}{ll}
\hline $\begin{array}{l}\text { Hobbies with poten- } \\
\text { tial lead exposure }\end{array}$ & $\begin{array}{l}\text { hunting/shooting, fishing, bullet and } \\
\text { lead casting }\end{array}$ \\
\hline Medical history & $\begin{array}{l}\text { head injury, electrical shock, bone frac- } \\
\text { tures, lead poisoning }\end{array}$ \\
\hline $\begin{array}{l}\text { Posttraumatic stress } \\
\text { disorder }\end{array}$ & $\begin{array}{l}\text { scale of 17-85 for intrusion, avoidance } \\
\text { and hyperarousal symptoms }\end{array}$ \\
\hline Family history & $\begin{array}{l}\text { diagnosis of ALS, Alzheimer disease, } \\
\text { Parkinson disease, Down's syndrome in } \\
\text { any first-degree relative }\end{array}$ \\
\hline Residential history & $\begin{array}{l}\text { all residences lived at for at least 6 } \\
\text { months since birth; city/town, state/ } \\
\text { country, urban vs. rural, proximity to } \\
\text { agricultural areas, source of water }\end{array}$ \\
\hline Physical activity & $\begin{array}{l}\text { recreational activities, competitive team } \\
\text { sport, organized sport (lifetime duration } \\
\text { and intensity) }\end{array}$ \\
\hline
\end{tabular}

inheritance. When the sample is restricted to an anticipated $\sim 40 \%$ of incident cases according to the above definition ( 250 cases, 1,000 controls), it will have $80 \%$ power to detect a main effect OR of 1.52 for a binary environmental exposure with population frequency $30 \%$, and $80 \%$ power to detect a gene-environment interaction OR of 1.97, assuming absence of main effects and a 30\% allele 


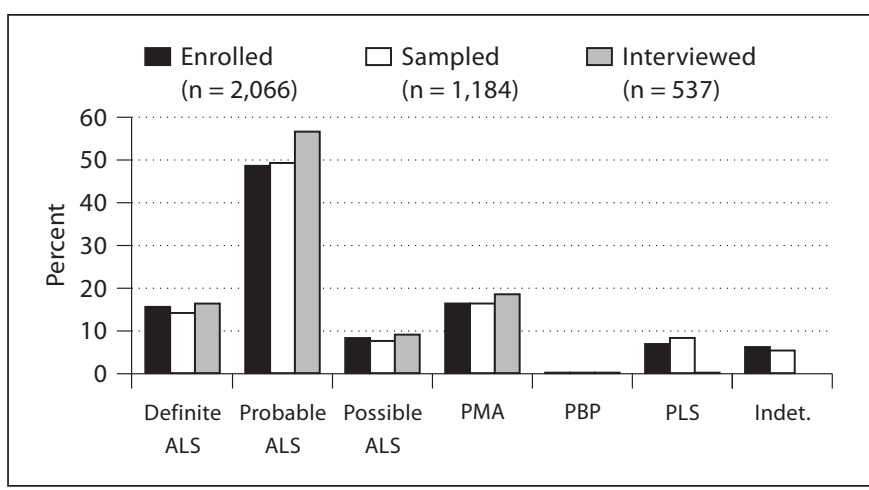

Fig. 2. Distribution of neurologist-confirmed diagnoses of ALS and MND for 3 groups of patients: (1) enrolled into National Registry of Veterans with ALS (excluding those with no ALS/MND diagnosis); (2) enrolled, with blood or mouthwash sample available in Registry DNA Bank; (3) enrolled and interviewed for GENEVA study. PMA = Progressive muscular atrophy; PBP = progressive bulbar palsy; PLS = primary lateral sclerosis; indet. $=$ indeterminate clinical status.

frequency with a log-additive mode of inheritance. A case-only analysis [87] will have $80 \%$ power to detect a gene-environment interaction OR of 1.42 (630 cases) and 1.75 ( 250 cases). For testing main genetic effects, the anticipated final sample (1,200 cases, 1,000 controls) will have $80 \%$ power to detect an OR of 1.20 for a $30 \%$ allele frequency with a log-additive mode of inheritance.

\section{Discussion}

We have summarized the study design and recruitment strategy used in the GENEVA study, which is presently enrolling a subset of VA registry participants as cases. One of the registry's initial scientific limitations was the lack of a control group and the difficulty in selecting such a group [66]. It is indeed a great challenge to identify an epidemiologically valid control group when the nationwide enrollment of both prevalent and incident cases is based on multiple recruitment strategies. Controls are much more readily identified for case recruitment strategies relying solely on database searches within a well-defined subpopulation of US veterans, such as those receiving health care from the VA system. However, an obvious disadvantage of such a study would be its smaller sample size and lack of generalizability, since the many US veterans obtaining health care at non-VA facilities would be excluded. Due to self-referrals, the VA ALS registry includes a substantial proportion of non-VA

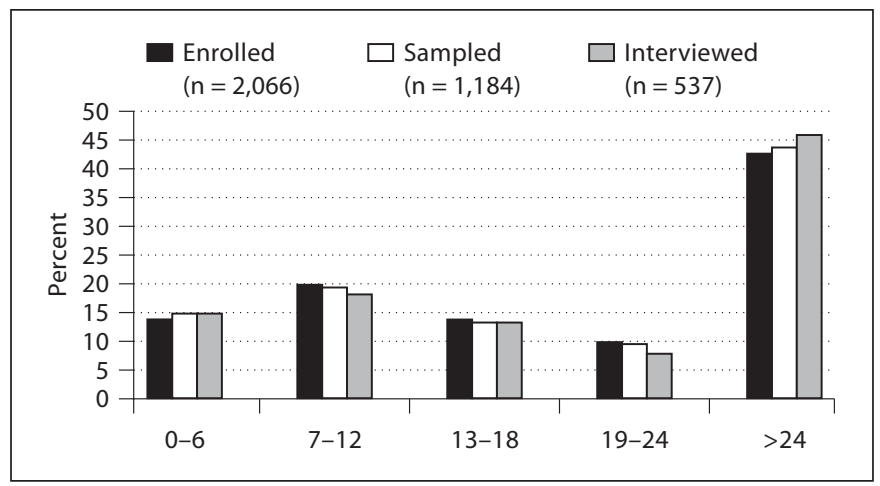

Fig. 3. Distribution of time between first ALS diagnosis and enrollment into National Registry of Veterans with ALS for 3 groups of patients: (1) enrolled into National Registry of Veterans with ALS (excluding those with no ALS/MND diagnosis); (2) enrolled, with blood or mouthwash sample available in Registry DNA Bank; (3) enrolled and interviewed for GENEVA study.

health care users; however, it is unclear whether the probability of participation in the registry was influenced by an individual's exposure history. Since the GENEVA study did not begin case recruitment until 2 years after the start of registry enrollment activities, its ideal pool of participants was further reduced by the high mortality of ALS patients and the burden of conducting an extensive telephone interview. For $25 \%$ of those who refused to be interviewed, including withdrawals after verbal consent, advanced disease was noted as the reason; in addition, 17 case interviews (3.2\%) remained incomplete, largely due to advanced disease as well. While the GENEVA participants are representative of the larger population of registry participants in terms of their primary disease characteristics, ALS patients with a very short survival period and fast progression rate are under-represented in this study population. For controls, the probability of participation was strongly related to age. Many younger individuals (age group 25-54 years) could not be contacted by telephone and were thus underrepresented among the study participants. The educational level of study participants was higher than that in the general US veteran population. Our data suggest that VA health care users in the control group were more likely than nonusers to participate in the study once telephone contact had been made. Interestingly, an analysis of VA registry participants demonstrated that those who were VA health care users at the time of enrollment into the registry, as opposed to the time of their first ALS diagnosis, were less 
likely to participate in the DNA bank component [68]. This finding may be related to differences in recruitment methods (active vs. passive) for VA users and non-users in the registry.

We initially considered the use of both active and passive recruitment strategies for controls, in order to mirror the recruitment process for cases. However, we ultimately decided to focus our efforts on active recruitment of the BIRLS-identified target population to avoid the problem that demographic characteristics and exposure histories of individuals motivated enough to respond to generic study advertisements may differ greatly from those of lessinterested individuals. This seemed particularly problematic with advertising of the study at veterans' service organizations. It is impossible to eliminate this type of selection bias altogether since refusal rates are almost always higher in controls than cases, often substantially so, and this is true for GENEVA as well. This general problem of low participation rates in contemporary epidemiologic studies has been discussed extensively in the literature $[88,89]$ and illustrates the challenge of conducting population-based studies in both veteran and civilian populations. It should be noted that the greatest concern about such biases relates to main effects of environmental exposures, which may have influenced the probability of participating in the study. Since individuals are usually not aware of their genetic background, the estimation of genetic main effects is more robust to these types of biases. While it is not impossible that willingness to participate may vary with genetic polymorphisms that influence an individual's behavior, a large study of almost 3,000 individuals and $>100$ polymorphisms did not detect such effects [90]. Estimates of gene-environment interaction may be obtained in an unbiased way from case-only analyses, as long as one can make a case for population independence of genetic polymorphism and environmental exposure [87, 91], or from analyses based on 'flexible matching' of cases and controls (at the analysis rather than design stage) on the environmental factor of interest [92].

We will utilize a variety of analytic strategies to address the potential of systematic biases in any study results reported in the future. Specifically, the following types of sensitivity analyses will address the possibility of selection and survival bias: (1) we will restrict the analysis to cases (currently 76.4\%) and controls (currently 82.4\%) who applied for at least one VA benefit, since the BIRLS database captures all veterans from this group; this is essentially the subgroup of all US veterans who have made any contact with the Department of Veterans Affairs; (2) we will compare the exposure history of cases who were identified through active versus passive recruitment strategies; (3) in order to address the question of how completely the registry has identified all US veterans with ALS who were alive (prevalent cases) or newly diagnosed (incident cases) between April 2003 and September 2007, we will perform capture-recapture analyses similar to those performed for the Persian Gulf War study [93]; (4) in order to address the possibility of survival bias, i.e. to distinguish exposure effects on ALS risk from effects on survival, we will restrict the analysis to incident cases; (5) a comparison of basic characteristics of the invited sample of potential controls, including those who could not be contacted or refused to participate, and the enrolled GENEVA controls (tables 1 and 2) will help evaluate bias and indicate which variables are potentially important to adjust for in the analysis of exposure variables.

We will also be able to evaluate potential bias by using publicly available information to compare the exposure history of GENEVA controls with that of the general US veteran population, including veterans who never contacted the VA. An example for this was shown in tables 1 and 2 with the demographic and military service characteristics of the estimated 25 million US veterans, based on the 2001 National Survey of Veterans. Another example is the Millennium Cohort Study, which is currently generating a wealth of exposure information for a very large representative sample of active duty and reserve/ guard service personnel $(>77,000$ participants in panel 1) who were identified from Department of Defense military service rosters in the year 2000 [79]. While the cohort is much younger than the GENEVA participants, analyses performed in the Millennium Cohort Study will provide ancillary information of relevance for our study population. For example, a linking of self-reported military occupational histories with electronic databases maintained by the Department of Defense demonstrated that self-reported military occupation can be used with a high degree of confidence [94]. The same study also identified particular occupational categories that were associated with higher odds of self-reported military exposures, such as witnessing death or trauma, contact with chemical or biological warfare agents, and exposure to depleted uranium or pesticides.

\section{Conclusion}

In summary, the GENEVA study is a unique resource for examining the joint effects of genetic susceptibility and environmental exposures on the risk of sporadic 
ALS. It will help determine whether any specific exposures common in the military population are responsible for the observation that military service may be associated with an increased ALS risk. This general hypothesis [65] and a more narrowly defined hypothesis that deployment to the Persian Gulf War may account for an increased risk [64] have recently received much attention [66]. Regardless of whether these hypotheses are ultimately confirmed or refuted, we believe that our study results will improve the limited understanding of the etiology of sporadic ALS in the general population, both military and civilian.

\section{Acknowledgements}

We are grateful to the ALS and MND patients and controls who have generously given their time to participate in this research. We acknowledge support for the GENEVA study from the National Institutes of Health (ES013244) and ALSA (1230). The National Registry of Veterans with ALS and its DNA bank were supported by the Office of Research and Development, Coopera- tive Studies Program, Department of Veterans Affairs (CSP 500A). Several members of the GENEVA study team used facilities at the Durham, N.C., VAMC during this project. The VA ALS Registry Group reviewed medical records of all patients enrolled into the ALS registry and includes the following neurologists in addition to EJK: Richard S. Bedlack, MD PhD, Joel C. Morgenlander, MD, and Marvin P. Rozear, MD, Duke University Medical Center and Durham VAMC, Durham, N.C., USA; Arman Sabet, MD, Neuroscience Department, Gold Coast Hospital, Southport, Australia (formerly University of Kentucky Medical Center and Lexington VAMC, Lexington, Ky., USA); Laura Sams, MD, University of Cincinnati Medical Center and Cincinnati VAMC, Cincinnati, Ohio, USA. We would also like to thank Paul Sullivan and Danita Cohen (Veterans Benefits Administration, Washington, D.C.) for their assistance in compiling the BIRLS sample, Everett (Chip) Lehman and Dovie Randolph (National Institute for Occupational Safety and Health, Cincinnati, Ohio, USA) and Beth Armstrong (Durham VAMC) for facilitating the IRS address merges, the ALS registry staff at the Durham VAMC (Lisa DiMartino, Karen Juntilla, Laurie Marbrey, Beverly McCraw, Honore Rowe and Priscilla Webster Williams) for their patient recruitment and medical record retrieval efforts, and Jennifer Hoff Lindquist, M.Stat., and Cynthia J. Coffman, Ph.D. (Durham VAMC, Duke University Medical Center) for assistance with database management and statistical analyses.

\section{References}

1 Yoshida S, Mulder DW, Kurland LT, Chu CP, Okazaki H: Follow-up study on amyotrophic lateral sclerosis in Rochester, Minn., 1925 through 1984. Neuroepidemiology 1986;5: 61-70.

-2 McGuire V, Longstreth WT Jr, Koepsell TD, Van Belle G: Incidence of amyotrophic lateral sclerosis in three counties in western Washington State. Neurology 1996;47:571-573.

-3 Traynor BJ, Codd MB, Corr B, Forde C, Frost E, Hardiman O: Incidence and prevalence of ALS in Ireland, 1995-1997: a populationbased study. Neurology 1999;52:504-509.

4 McGuire V, Nelson LM: Epidemiology of ALS; in Mitsumoto H, Przedborski S, Gordon P (eds): Amyotrophic Lateral Sclerosis. New York, Taylor \& Francis, 2006, pp 17-21.

5 Cronin S, Hardiman O, Traynor BJ: Ethnic variation in the incidence of ALS: a systematic review. Neurology 2007;68:1002-1007.

6 Kunst CB: Complex genetics of amyotrophic lateral sclerosis. Am J Hum Genet 2004;75: 933-947.

7 Rosen DR, Siddique T, Patterson D, Figlewicz DA, Sapp P, Hentati A, Donaldson D, Goto J, O’Regan JP, Deng HX, Rahmani Z, Krizus A, McKenna-Yasek D, Cayabyab A, Gaston SM, Berger R, Tanzi RE, Halperin JJ, Herzfeldt B, Van den Bergh R, Hung WY, Bird T, Deng G, Mulder DW, Smyth C, Laing NG, Soriano E, Pericak-Vance MA, Haines J, Rouleau GA, Gusella J, Horvitz HR, Brown $\mathrm{RH}$ Jr: Mutations in $\mathrm{Cu} / \mathrm{Zn}$ superoxide dis- mutase gene are associated with familial amyotrophic lateral sclerosis. Nature 1993; 362:59-62.

8 Chio A, Brignolio F, Meineri P, Schiffer D: Phenotypic and genotypic heterogeneity of dominantly inherited amyotrophic lateral sclerosis. Acta Neurol Scand 1987;75:277282.

-9 Bruijn LI, Miller TM, Cleveland DW: Unraveling the mechanisms involved in motor neuron degeneration in ALS. Annu Rev Neurosci 2004;27:723-749.

10 Mitchell J: Amyotrophic lateral sclerosis: toxins and environment. Amyotroph Lateral Scler Other Motor Neuron Disord 2000;1: 235-250.

11 Schmidt S, Vance JM: Genetic causes and predisposition; in Mitsumoto $\mathrm{H}$, Przedborski S, Gordon P (eds): Amyotrophic Lateral Sclerosis. New York, Taylor \& Francis, 2006, pp 449-485.

12 Lambrechts D, Storkebaum E, Morimoto M, Del-Favero J, Desmet F, Marklund SL, Wyns S, Thijs V, Andersson J, van Marion I, AlChalabi A, Bornes S, Musson R, Hansen V, Beckman L, Adolfsson R, Pall HS, Prats H, Vermeire S, Rutgeerts P, Katayama S, Awata T, Leigh N, Lang-Lazdunski L, Dewerchin M, Shaw C, Moons L, Vlietinck R, Morrison KE, Robberecht W, Van Broeckhoven C, Collen D, Andersen PM, Carmeliet P: VEGF is a modifier of amyotrophic lateral sclerosis in mice and humans and protects motoneu- rons against ischemic death. Nat Genet 2003; 34:383-394.

-13 Terry PD, Kamel F, Umbach DM, Lehman TA, $\mathrm{Hu}$ H, Sandler DP, Taylor JA: VEGF promoter haplotype and amyotrophic lateral sclerosis (ALS). J Neurogenet 2004;18:429-434.

- 14 Fernandez-Santiago R, Sharma M, Mueller JC, Gohlke H, Illig T, Anneser J, Munch C, Ludolph A, Kamm C, Gasser T: Possible gender-dependent association of vascular endothelial growth factor (VEGF) gene and ALS. Neurology 2006;66:1929-1931.

15 Greenway MJ, Alexander MD, Ennis S, Traynor BJ, Corr B, Frost E, Green A, Hardiman O: A novel candidate region for ALS on chromosome 14q11.2. Neurology 2004;63: 1936-1938.

16 Greenway MJ, Andersen PM, Russ C, Ennis S, Cashman S, Donaghy C, Patterson V, Swingler R, Kieran D, Prehn J, Morrison KE, Green A, Acharya KR, Brown RH Jr, Hardiman O: ANG mutations segregate with familial and 'sporadic' amyotrophic lateral sclerosis. Nat Genet 2006;38:411-413.

17 Hayward C, Colville S, Swingler RJ, Brock DJH: Molecular genetic analysis of the APEX nuclease gene in amyotrophic lateral sclerosis (ALS). Neurology 1999;52:1899-1901.

18 Goodall EF, Greenway MJ, van Marion I, Carroll CB, Hardiman O, Morrison KE: Association of the H63D polymorphism in the hemochromatosis gene with sporadic ALS. Neurology 2005;65:934-937. 
19 Sutedja NA, Sinke RJ, Van Vught PW, van der Linden MW, Wokke JH, Van Duijn CM, Njajou OT, Van der Schouw YT, Veldink JH, Van den Berg LH: The association between H63D mutations in HFE and amyotrophic lateral sclerosis in a Dutch population. Arch Neurol 2007;64:63-67.

-20 Veldink JH, Kalmijn S, Van der Hout AH, Lemmink HH, Groeneveld GJ, Lummen C, Scheffer H, Wokke JH, Van den Berg LH: $S M N$ genotypes producing less $S M N$ protein increase susceptibility to and severity of sporadic ALS. Neurology 2005;65:820-825.

21 Corcia P, Camu W, Halimi JM, Vourc'h P, Antar C, Vedrine S, Giraudeau B, de Toffol B, Andres CR: SMN1 gene, but not SMN2, is a risk factor for sporadic ALS. Neurology 2006;67:1147-1150.

-22 Saeed M, Siddique N, Hung WY, Usacheva E, Liu E, Sufit RL, Heller SL, Haines JL, Pericak-Vance M, Siddique T: Paraoxonase cluster polymorphisms are associated with sporadic ALS. Neurology 2006;67:771-776.

23 Slowik A, Tomik B, Wolkow PP, Partyka D, Turaj W, Malecki MT, Pera J, Dziedzic T, Szczudlik A, Figlewicz DA: Paraoxonase gene polymorphisms and sporadic ALS. Neurology 2006;67:766-770.

-24 Morahan JM, Yu B, Trent RJ, Pamphlett RA: Gene-environment study of the paraoxonase 1 gene and pesticides in amyotrophic lateral sclerosis. Neurotoxicology 2007;28:532540.

-25 Cronin S, Greenway MJ, Prehn JH, Hardiman O: Paraoxonase promoter and intronic variants modify risk of sporadic amyotrophic lateral sclerosis. J Neurol Neurosurg Psychiatry 2007;78:984-986.

-26 Furlong CE, Li WF, Brophy VH, Jarvik GP, Richter RJ, Shih DM, Lusis AJ, Costa LG: The $P O N 1$ gene and detoxication. Neurotoxicology 2000;21:581-587.

-27 Haley RW, Billecke S, La Du BN: Association of low PON1 type Q (type A) arylesterase activity with neurologic symptom complexes in Gulf War veterans. Toxicol Appl Pharmacol 1999;157:227-233.

28 Al-Chalabi A, Enayat ZE, Bakker MC, Sham PC, Ball DM, Shaw CE, Lloyd CM, et al: Association of apolipoprotein $\mathrm{E} \varepsilon 4$ allele with bulbar-onset motor neuron disease. Lancet 1996;347:159-160.

-29 Moulard B, Sefiani A, Laamri A, Malafosse A, Camu W: Apolipoprotein E genotyping in sporadic amyotrophic lateral sclerosis: evidence for a major influence on the clinical presentation and prognosis. J Neurol Sci 1996;139(suppl):34-37.

- 30 Smith RG, Haverkamp LJ, Case S, Appel V, Appel SH: Apolipoprotein E $\varepsilon 4$ in bulbaronset motor neuron disease. Lancet 1996; 348:334-335.
31 Li YJ, Pericak-Vance MA, Haines JL, Siddique N, McKenna-Yasek D, Hung WY, Sapp P, Allen CI, Chen W, Hosler B, Saunders AM, Dellefave LM, Brown RH Jr, Siddique T: Apolipoprotein $\mathrm{E}$ is associated with age at onset of amyotrophic lateral sclerosis. Neurogenetics 2004;5:209-213.

32 Schymick JC, Scholz SW, Fung HC, Britton A, Arepalli S, Gibbs JR, Lombardo F, Matarin $M$, Kasperaviciute D, Hernandez DG, Crews C, Bruijn L, Rothstein J, Mora G, Restagno G, Chio A, Singleton A, Hardy J, Traynor BJ: Genome-wide genotyping in amyotrophic lateral sclerosis and neurologically normal controls: first stage analysis and public release of data. Lancet Neurol 2007;6: 322-328.

33 Dunckley T, Huentelman MJ, Craig DW, Pearson JV, Szelinger S, Joshipura K, Halperin RF, Stamper C, Jensen KR, Letizia D, Hesterlee SE, Pestronk A, Levine T, Bertorini T, Graves MC, Mozaffar T, Jackson CE, Bosch P, McVey A, Dick A, Barohn R, Lomen-Hoerth C, Rosenfeld J, O'Connor DT, Zhang K, Crook R, Ryberg H, Hutton M, Katz J, Simpson EP, Mitsumoto H, Bowser R, Miller RG, Appel SH, Stephan DA: Wholegenome analysis of sporadic amyotrophic lateral sclerosis. N Engl J Med 2007;357:775788.

34 van Es MA, Van Vught PW, Blauw HM, Franke L, Saris CG, Andersen PM, Van Den Bosch L, de Jong SW, van't Slot R, Birve A, Lemmens R, de Jong V, Baas F, Schelhaas HJ, Sleegers K, Van Broeckhoven C, Wokke JH, Wijmenga C, Robberecht W, Veldink JH, Ophoff RA, Van den Berg LH: ITPR2 as a susceptibility gene in sporadic amyotrophic lateral sclerosis: a genome-wide association study. Lancet Neurol 2007;6:869-877.

- 35 Cronin S, Berger S, Ding J, Schymick JC, Washecka N, Hernandez DG, Greenway MJ, Bradley DG, Traynor BJ, Hardiman O: A genome-wide association study of sporadic ALS in a homogenous Irish population. Hum Mol Genet 2008;17:768-774.

-36 Deapen DM, Henderson BE: A case-control study of amyotrophic lateral sclerosis. Am J Epidemiol 1986;123:790-799.

- 37 Savettieri G, Salemi G, Arcara A, Cassata M, Castiglione MG, Fierro BA: Case-control study of amyotrophic lateral sclerosis. Neuroepidemiology 1991;10:242-245.

38 McGuire V, Longstreth WT Jr, Nelson LM, Koepsell TD, Checkoway H, Morgan MS, Van Belle G: Occupational exposures and amyotrophic lateral sclerosis: a populationbased case-control study. Am J Epidemiol 1997;145:1076-1088.

39 Campbell AM, Williams ER, Barltrop D: Motor neurone disease and exposure to lead. J Neurol Neurosurg Psychiatry 1970;33:877885.

40 Armon C, Kurland LT, Daube JR, O’Brien PC: Epidemiologic correlates of sporadic amyotrophic lateral sclerosis. Neurology 1991;41:1077-1084.
41 Chancellor AM, Slattery JM, Fraser H, Warlow CP: Risk factors for motor neuron disease: a case-control study based on patients from the Scottish Motor Neuron Disease Register. J Neurol Neurosurg Psychiatry 1993;56:1200-1206.

-42 Kamel F, Umbach DM, Munsat TL, Shefner JM, Hu H, Sandler DP: Lead exposure and amyotrophic lateral sclerosis. Epidemiology 2002;13:311-319.

43 Felmus MT, Patten BM, Swanke L: Antecedent events in amyotrophic lateral sclerosis. Neurology 1976;26:167-172.

44 Pierce-Ruhland R, Patten BM: Repeat study of antecedent events in motor neuron disease. Ann Clin Res 1981;13:102-107.

45 Gresham LS, Molgaard CA, Golbeck AL, Smith R: Amyotrophic lateral sclerosis and occupational heavy metal exposure: a casecontrol study. Neuroepidemiology 1986;5: 29-38.

46 Gunnarsson LG, Bodin L, Söderfeldt B, Axelson O: A case-control study of motor neurone disease: its relation to heritability, and occupational exposures, particularly to solvents. Br J Ind Med 1992;49:791-798.

47 Kamel F, Umbach DM, Munsat TL, Shefner JM, Sandler DP: Association of cigarette smoking with amyotrophic lateral sclerosis. Neuroepidemiology 1999;18:194-202.

48 Nelson LM, McGuire V, Longstreth WT Jr, Matkin C: Population-based case-control study of amyotrophic lateral sclerosis in western Washington State. I. Cigarette smoking and alcohol consumption. Am J Epidemiol 2000;151:156-163.

49 Weisskopf MG, McCullough ML, Calle EE, Thun MJ, Cudkowicz M, Ascherio A: Prospective study of cigarette smoking and amyotrophic lateral sclerosis. Am J Epidemiol 2004;160:26-33.

50 Longstreth WT, McGuire V, Koepsell TD, Wang Y, Van Belle G: Risk of amyotrophic lateral sclerosis and history of physical activity: a population-based case-control study. Arch Neurol 1998;55:201-206.

51 Chio A, Benzi G, Dossena M, Mutani R, Mora G: Severely increased risk of amyotrophic lateral sclerosis among Italian professional football players. Brain 2005;128: 472-476.

52 Belli S, Vanacore N: Proportionate mortality of Italian soccer players: is amyotrophic lateral sclerosis an occupational disease? Eur J Epidemiol 2005;20:237-242.

53 Kondo K, Tsubaki T: Case-control studies of motor neuron disease: association with mechanical injuries. Arch Neurol 1981;38:220226.

54 Chen H, Richard M, Sandler DP, Umbach DM, Kamel F: Head injury and amyotrophic lateral sclerosis. Am J Epidemiol 2007;166: 810-816.

55 Kurtzke JF, Beebe GW: Epidemiology of amyotrophic lateral sclerosis: 1. A case-control comparison based on ALS deaths. Neurology 1980;30:453-462. 
56 Gallagher JP, Sanders M: Trauma and amyotrophic lateral sclerosis: a report of 78 patients. Acta Neurol Scand 1987;75:145-150.

57 Gresham LS, Molgaard CA, Golbeck AL, Smith R: Amyotrophic lateral sclerosis and history of skeletal fracture: a case-control study. Neurology 1987;37:717-719.

-58 Granieri E, Carreras M, Tola R, Paolino E, Tralli G, Eleopra R, Serra G: Motor neuron disease in the province of Ferrara, Italy, in 1964-1982. Neurology 1988;38:1604-1608.

-59 Williams DB, Annegers JS, Kokman E, O'Brien PC, Kurland LT: Brain injury in neurologic sequalae: a cohort study of dementia, parkinsonism, and amyotrophic lateral sclerosis. Neurology 1991;41:1554-1557.

-60 Chio A, Meineri P, Tribolo A, Schiffer D: Risk factors in motor neuron disease: a casecontrol study. Neuroepidemiology 1991;10: 174-184.

-61 Kamel F, Umbach DM, Lehman TA, Park LP, Munsat TL, Shefner JM, Sandler DP, Hu H, Taylor JA: Amyotrophic lateral sclerosis, lead, and genetic susceptibility: polymorphisms in the delta-aminolevulinic acid dehydratase and vitamin $\mathrm{d}$ receptor genes. Environ Health Perspect 2003;111:1335-1339.

62 Smith TC, Gray GC, Knoke JD: Is systemic lupus erythematosus, amyotrophic lateral sclerosis, or fibromyalgia associated with Persian Gulf War service? An examination of department of defense hospitalization data. Am J Epidemiol 2000;151:1053-1059.

-63 Haley RW: Excess incidence of ALS in young Gulf War veterans. Neurology 2003;61:750756.

64 Horner RD, Kamins KG, Feussner JR, Grambow SC, Hoff-Lindquist J, Harati Y, Mitsumoto H, Pascuzzi R, Spencer PS, Tim R, Howard D, Smith TC, Ryan MA, Coffman CJ, Kasarskis EJ: Occurrence of amyotrophic lateral sclerosis among Gulf War veterans. Neurology 2003;61:742-749.

-65 Weisskopf MG, O’Reilly EJ, McCullough ML, Calle EE, Thun MJ, Cudkowicz M, Ascherio A: Prospective study of military service and mortality from ALS. Neurology 2005;64:32-37.

66 Institute of Medicine Committee on the Review of the Scientific Literature on Amyotrophic Lateral Sclerosis in Veterans: Amyotrophic lateral sclerosis in veterans: review of the scientific literature. National Academies Press, 2006. http://www.nap.edu/catalog/ 11757.html.

67 Kasarkis EJ, Dominic K, Oddone EZ: The National Registry of Veterans with Amyotrophic Lateral Sclerosis: Department of Veterans Affairs Cooperative Studies Program (CSP) \#500a. Amyotroph Lateral Scler Other Motor Neuron Disord 2004;5(suppl 1):129-132.

-68 DiMartino L, Allen KD, Kasarskis E, Lindquist JH, Coffman CJ, Oddone EZ: Characteristics associated with participation in DNA banking: The National Registry of Veterans with ALS. Contemp Clin Trials 2007;28:572-582.
69 Brooks BR: El Escorial World Federation of Neurology criteria for the diagnosis of amyotrophic lateral sclerosis. Subcommittee on Motor Neuron Diseases/Amyotrophic Lateral Sclerosis of the World Federation of Neurology Research Group on Neuromuscular Diseases and the El Escorial "Clinical limits of amyotrophic lateral sclerosis" workshop contributors. J Neurol Sci 1994;124 (suppl):96-107.

70 Brooks BR, Miller RG, Swash M, Munsat T: El Escorial revisited: revised criteria for the diagnosis of amyotrophic lateral sclerosis. Amyotroph Lateral Scler Other Motor Neuron Disord 2000;1:293-299.

71 Kubal JD, Webber S, Cowper DC, Waight S, Hynes DM: A primer on major US mortality databases used in health services research. VIReC Insights 2000;5:1-4. http://www.virec. research.va.gov/HistoricalDocuments/ VirecInsights/Insights-v01n5.pdf

72 Boyle CA, Decoufle P: National sources of vital status information: extent of coverage and possible selectivity in reporting. Am J Epidemiol 1990;131:160-168.

73 Page WF, Braun MM, Caporaso NE: Ascertainment of mortality in the US veteran population: World War II veteran twins. Mil Med 1995;160:351-355.

74 Fisher SG, Weber L, Goldberg J, Davis F: mortality ascertainment in the veteran population: alternatives to the National Death Index. Am J Epidemiol 1995;141:242-250.

75 Larson RJ, Welch HG: Risk for increased utilization and adverse health outcomes among men served by the Veterans Health Administration. Mil Med 2007;172:690-696.

76 Dillman DA: Mail and Internet Surveys: The Tailored Design Method, ed 2. New York, Wiley \& Sons, 2000.

77 Gauderman WJ: Sample size requirements for matched case-control studies of gene-environment interaction. Stat Med 2002;21: 35-50.

78 Doebbeling BN, Jones MF, Hall DB, Clarke WR, Woolson RF, Torner JC, Burmeister LF, Snyders-Crumley T, Barrett DH, Falter KH, Merchant JA, Nusser S, Anderson D, Schwartz DA: Methodologic issues in a population-based health survey of Gulf War veterans. J Clin Epidemiol 2002;55:477-487.

79 Ryan MA, Smith TC, Smith B, Amoroso P, Boyko EJ, Gray GC, Gackstetter GD, Riddle JR, Wells TS, Gumbs G, Corbeil TE, Hooper TI: Millennium Cohort: enrollment begins a 21-year contribution to understanding the impact of military service. J Clin Epidemiol 2007;60:181-191.

80 Weathers FW, Litz BT, Herman DS, Huska JA, Keane TM: The PTSD Checklist Military Version (PCL-M). Boston, National Center for PTSD, 1991. http://www.pdhealth.mil/ guidelines/appendix4.asp.
81 Weathers FW, Litz BT, Herman DS, Huska JA, Keane TM: The PTSD checklist: reliability, validity, and diagnostic utility (abstract). Annu Meet Int Soc Trauma Stress Studies, San Antonio, Tex., 1993.

82 Lang AJ, Laffaye C, Satz LE, Dresselhaus TR, Stein MB: Sensitivity and specificity of the PTSD checklist in detecting PTSD in female veterans in primary care. J Trauma Stress 2003;16:257-264.

83 Brewin CR: Systematic review of screening instruments for adults at risk of PTSD. J Trauma Stress 2005; 18:53-62.

84 Chio A: ISIS Survey: an international study on the diagnostic process and its implications in amyotrophic lateral sclerosis. J Neurol 1999;246(suppl 3):III1-III5.

-85 Stewart WF, Stewart, PA: Occupational casecontrol studies. I. Collecting information on work histories and work-related exposures. Am J Ind Med 1994;26:297-312.

86 Stewart PA, Stewart WF: Occupational casecontrol studies. II. Recommendations for exposure assessment. Am J Ind Med 1994;26: 313-326.

87 Piegorsch WW, Weinberg CR, Taylor JA: Non-hierarchical logistic models and caseonly designs for assessing susceptibility in population-based case-control studies. Stat Med 1994;13:153-162.

88 Morton LM, Cahill J, Hartge P: Reporting participation in epidemiologic studies: a survey of practice. Am J Epidemiol 2006;163: 197-203.

89 Hartge P: Participation in population studies. Epidemiology 2006;17:252-254.

90 Bhatti P, Sigurdson AJ, Wang SS, Chen J, Rothman N, Hartge P, Bergen AW, Landi MT: Genetic variation and willingness to participate in epidemiologic research: data from three studies. Cancer Epidemiol Biomarkers Prev 2005; 14:2449-2453.

-91 Gatto NM, Campbell UB, Rundle AG, Ahsan $\mathrm{H}$ : Further development of the case-only design for assessing gene-environment interaction: evaluation of and adjustment for bias. Int J Epidemiol 2004;33:1014-1024.

-92 Sturmer T, Brenner H: Flexible matching strategies to increase power and efficiency to detect and estimate gene-environment interactions in case-control studies. Am J Epidemiol 2002;155:593-602.

93 Coffman CJ, Horner RD, Grambow SC, Lindquist J: Estimating the occurrence of amyotrophic lateral sclerosis among Gulf War (1990-1991) veterans using capture-recapture methods. Neuroepidemiology 2005; 24:141-150.

94 Smith TC, Jacobson IG, Smith B, Hooper TI, Ryan MA, Team FT: The occupational role of women in military service: validation of occupation and prevalence of exposures in the Millennium Cohort Study. Int J Environ Health Res 2007;17:271-284 